\title{
IMPLEMENTASI PERATURAN GUBERNUR PROVINSI DAERAH KHUSUS IBUKOTA JAKARTA NOMOR 10 TAHUN 2015 TENTANG KEBIJAKAN PENATAAN DAN PEMBERDAYAAN PEDAGANG KAKI LIMA DI KELURAHAN GUNTUR KECAMATAN SETIABUDI JAKARTA SELATAN
}

\author{
Narip Aripin*); Hyronimus Rowa; Etin Indrayani \\ Pascasarjana Institut Pemerintahan Dalam Negeri Jakarta \\ *email:naripinnarip123@gmail.com
}

Paper Accepted: 26 Juni 2021

Paper Reviewed: 27-30 Juni 2021

Paper Edited: 01-06 Juli 2021

Paper Approved: 07 Juli 2021

\begin{abstract}
ABSTRAK
Penelitian ini dilakukan untuk melihat sejauhmana implementasi Peraturan Gubernur Provinsi DKI Jakarta Nomor 10 Tahun 2015 tentang Penataan dan Pemberdayaan Pedagang Kaki Lima di kawasan Setiabudi, Jakarta. Penelitian ini menggunakan metode kualitatif dengan jenis penelitian Yuridis Empiris. Hasil penelitian menunjukkahn bahwa penataan pedagang kaki lima di DKI Jakarta perlu dilakukan mengingat kondisi pedagang kaki lima yang semakin bertambah dan berkembang. Selain itu, juga karena masih banyak pedagang kaki lima yang tidak memiliki izin usaha. Kendalakendala yang dihadapi Pemerintah Daerah DKI Jakarta dalam penataan dan pemberdayaan pedagang kaki lima antara lain: banyak pedagang kaki lima di DKI Jakarta yang berjualan tidak pada tempatnya dan tidak tertata; masih banyak pedagang kaki lima yang tidak memiliki izin usaha; tidak ada lahan atau tempat khusus bagi pedagang kaki lima; masih banyak pedagang kaki lima yang tidak mengerti dan kurang paham tentang Peraturan Daerah DKI Jakarta Nomor 8 Tahun 2007 tentang Ketertiban Umum; dan belum adanya jaminan pengganti lokasi usaha bagi pedagang kaki lima dari Pemerintah Daerah DKI Jakarta.
\end{abstract}

Kata Kunci : Kebijakan, Ketertiban Umum, Pedagang Kaki Lima

\section{PENDAHULUAN}

\section{Latar Belakang}

Kehadiran PKL merupakan salah satu faktor yang menimbulkan persoalan, baik dalam masalah ketertiban, lalulintas, keamanan, maupun kebersihan di setiap daerah termasuk juga di DKI Jakarta. Berbagai permasalahan terkait dengan PKL banyak bermunculan yang ternyata merugikan masyarakat dan juga pemerintah daerah sendiri seperti rasa tidak nyaman karena keberadaan PKL yang tidak pada tempatnya sehingga mengganggu kegiatan masyarakat sehari-hari. Selain itu ada juga PKL yang mendirikan bangunan tempat usahanya secara permanen yang sekaligus digunakan untuk tempat tinggal, hal ini juga bisa mendatangkan kesulitan bagi pemerintah daerah dalam menghadapi sikap dan kemauan para PKL ketika suatu saat akan ditata. PKL ini timbul akibat tidak tersedianya lapangan pekerjaan bagi rakyat kecil yang tidak memiliki kemampuan untuk mencari pekerjaan demi mendapatkan pendapatan guna memenuhi kebutuhan hidupnya seharihari. Pemerintah dalam hal ini sebenarnya memiliki tanggung jawab di dalam 
melaksanakan pembangunan dibidang pendidikan, bidang perekonomian dan penyediaan lapangan pekerjaan.

Sejalan dengan semangat otonomi daerah, setiap pemerintah daerah berupaya mengembangkan berbagai strategi atau kebijakan untuk menangani persoalan PKL dari mulai yang bersifat persuasif hingga represif. Jika pemerintah melihat PKL sebagai potensi sosial ekonomi yang bisa dikembangkan, maka kebijakan yang dipilih biasanya akan lebih diarahkan untuk menata PKL, misalnya dengan memberikan ruang usaha bagi PKL, memformalkan status mereka sehingga bisa memperoleh bantuan kredit bank, dan lainnya. Namun sebaliknya, jika PKL hanya dilihat sebagai pengganggu ketertiban dan keindahan kota, maka mereka akan menjadi sasaran penggusuran dan penertiban. Jadi sangat wajar sekali fenomena PKL ini merupakan imbas dari semakin banyaknya jumlah rakyat miskin dan tidak cukup tersedianya lapangan pekerjaan di Indonesia. Mereka berdagang hanya karena tidak ada pilihan lain, tidak memiliki kemampuan pendidikan yang memadai, dan tidak memiliki tingkat pendapatan ekonomi yang baik dan sempitnya lapangan pekerjaan yang tersedia buat mereka. Sehingga untuk memenuhi kebutuhan pokok sehari-hari dan untuk membiayai keluarganya ia harus bekerja sebagai PKL.

Pengamatan yang dilakukan oleh penulis bahwa: Pedagang Kaki Lima yang ada di Kawasan Kecamatan Setiabudi, meskipun sudah tertata dengan rapi tetapi masih mengganggu lalu lintas jalan raya tersebut. Selain itu para PKL menggunakan pinggiran jalan untuk menggelar dagangannya, padahal pinggiran jalan itu dibuat untuk pejalan kaki. Dengan dipakainya pinggiran jalan untuk berjualan, maka pejalan kaki menggunakan sebagian jalan raya untuk berjalan, hal inilah yang membuat kemacetan.

Jakarta, sekalipun telah diakui terjadi berbagai kemajuan dalam hal pembangunan fisik, tetapi kita tidak bisa menutup mata bahwa di saat yang sama juga masih menyisakan berbagai masalah sosial yang tak kalah pelik.

Di berbagai sudut kota, setiap hari dengan mudah disaksikan asongan yang kadang mengganggu. Terutama aktivitas Pedagang Kaki Lima di Kawasan Kecamatan
Setiabudi yang menjajakan dagangannya tanpa mengindahkan aturan yang ada.

\section{Perumusan Masalah}

1. Bagaimana implementasi Pergub Provinsi DKI Nomor 10 tahun 2015 tentang Penataan dan Pemberdayaan Pedagang Kaki Lima di Kecamatan Setiabudi?

2. Hambatan dan kendala apa yang di temui dalam implementasi Pergub Provinsi DKI Nomor 10 tahun 2015 tentang Penataan dan Pemberdayaan Pedagang Kaki Lima di Kecamatan Setiabudi?

3. Bagaimana strategi yang di terapkan dalam mengimplementasikan Pergub Provinsi DKI Nomor 10 tahun 2015 tentang Penataan dan Pemberdayaan Pedagang Kaki Lima di Kecamatan Setiabudi?

\section{Maksud dan Tujuan Penelitian}

1. Untuk mengetahui Pelaksanaan Pergub Provinsi DKI Nomor 10 tahun 2015 tentang Penataan dan Pemberdayaan Pedagang Kaki Lima di Kecamatan Setiabudi.

2. Untuk mengetahui hambatan pelaksanaan Pergub Provinsi DKI Nomor 10 tahun 2015 tentang Penataan dan Pemberdayaan Pedagang Kaki Lima di Kecamatan Setiabudi.

3. Untuk mengetahui strategi yang di terapkan dalam mengimplementasikan Pergub Provinsi DKI Nomor 10 tahun 2015 tentang Penataan dan Pemberdayaan Pedagang Kaki Lima di Kecamatan Setiabudi.

\section{Waktu dan Tempat Penelitian}

Lokasi penelitian ini dilakukan di Kelurahan Guntur Kecamatan Setiabudi Jakarta Selatan. Alasan pemilihan Kelurahan Guntur sebagai lokasi penelitian adalah karena Pedagang Kaki Lima (PKL) yang ada di kawasan Kecamatan Setiabudi, meskipun sudah tertata dengan rapi tetapi masih mengganggu lalu lintas jalan raya tersebut.

Selain itu para PKL menggunakan pinggiran jalan untuk menggelar 
dagangannya, padahal pinggiran jalan itu dibuat untuk pejalan kaki. Dengan dipakainya pinggiran jalan untuk berjualan, maka pejalan kaki menggunakan sebagian jalan raya untuk berjalan, hal inilah yang membuat kemacetan.

\section{Gambaran Umum Lokasi dan Institusi Penelitian}

\section{Lokasi Penelitian}

Kecamatan Setiabudi merupakan salah satu kecamatan di Kotamadya Jakarta Selatan yang memiliki luas wilayah sebesar $8,85 \mathrm{~km} 2$. Secara geografis, kecamatan ini terletak pada 06 15' 40, 8' LS dan 106 45'00, 0" BT dan merupakan daerah dataran yang berada pada ketinggian 26, $2 \mathrm{~m}$ di atas permukaan laut. Secara umum batas wilayah Kecamatan Setiabudi adalah:

Utara: Berbatasan dengan Kali Malang Kota Administrasi Jakarta Pusat. Timur: Berbatasan dengan Jl. Prof. Dr. Sahardjo Kecamatan Tebet.

Selatan: Berbatasan dengan Jl. Jend Gatot Subroto Kecamatan Kebayoran Baru. Barat: Berbatasan dengan Jl. Jend Sudirman Kota Administrasi Jakarta Pusat.

Secara Administratif, Kecamatan Setiabudi terdiri dari 8 (delapan) kelurahan, 50 RW, dan 514 RT. Delapan kelurahan tersebut adalah Karet Semanggi, Kuningan Timur, Karet Kuningan, Karet, Guntur, Setiabudi, Menteng Atas, dan Pasar Manggis. Dari kedelapan kelurahan itu kelurahan yang paling banyak penduduknya adalah Kelurahan Menteng Atas dan Kelurahan Pasar Manggis. Hal ini dikarenakan kedua kelurahan tersebut merupakan daerah emukiman padat penduduk, kelurahan lainnya yang didominasi oleh gedung-gedung perkantoran.

\section{Institusi Penelitian}

Berdasarkan ketentuan pasal 151 Peraturan Daerah Nomor 10 tahun 2008 tentang Organisasi Perangkat Daerah, maka perlu ditetapkannya Peraturan Gubernur tentang organisasi dan tata kerja kecamatan. Berdasarkan hal inilah, maka dibentuk Peraturan Gubernur Provinsi Daerah dan Khusus Ibukota Jakarta nomor 146 Tahun 2009 tentang organisasi dan tata kerja Kecamatan. Kecamatan merupakan perangkat daerah dibawah Kota Administrasi
/ Kabupaten Administrasi. Kecamatan di pimpin oleh Camat yang berkududukan di bawah dan bertanggung jawab kepada Walikota/Bupati melalui Sekretaris Kota Administrasi / Kabupaten Administrasi, dalam melaksanakan tugas dan fungsinya Kecamatan di kordinasikan oleh asisten pemerintahan dan juga oleh seorang camat.

\section{METODE PENELITIAN}

\section{Desain Penelitian}

Desain penelitian adalah kerangka atau cetak biru dalam melaksanakan suatu proyek riset. Suatu prosedur penting untuk informasi yang dibutuhkan untuk menyusun masalah penelitian.

Desain penelitan dibagi menjadi dua bagian besar, yaitu secara menyeluruh dan parsial.

1. Secara menyeluruh, desain penelitian adalah semua proses yang dilakukan dalam perencanaan dalam pelaksanaan penelitian. Dalam hal ini komponen desain dapat mencakup semua struktur penelitian diawali saat menemukan ide, menentukan tujuan, kemudian merencanakan penelitian (permasalahan, merumuskan, menentukan tujuan penelitian, sumber imformasi dan melakukan kajian dari berbagai pustaka, menentukan metode yang digunakan, analisis data, dan menguji hopotesis untuk mendapatkan hasil penelitian).

2. Desain penelitian secara parsial merupakan penggambaran tentang hubungan antarvariabel, pengumpulan data, dan analisis data, sehingga dengan adanya desain yang baik peneliti maupun pihak yang berkepentingan mempunyai gambaran yang jelas tentang keterkaitan antara variabel yang ada dalam konteks penelitian dan apa yang hendak dilakukan oleh seorang peneliti dalam melaksanakan penelitian (Malhotra; 2007) 
Metode Penelitian

Penelitian ini menggunakan metode kualitatif dengan jenis penelitian Yuridis Empiris, yakni sebuah peninjauan penelitian yang mengumpulkan fakta-fakta sosial atau permasalahan hukum secara terstruktur dan materi hukum positif dapat diperoleh dari kegiatan mempelajari bahan-bahan hukum terkait (Bahder; 2008).

\section{HASIL PENELITIAN DAN PEMBAHASAN}

Implementasi Kebijakan Pergub DKI Jakarta Nomor 10 Tahun 2015 tentang Penataan dan Pemberdayaan Pedagang Kaki Lima di Kecamatan Setia Budi Jakarta Selatan

Penelitian ini merupakan penelitian kualitatif yang bersifat deskriptif tentang Implementasi Pergub DKI Jakarta Nomor 10 Tahun 2015 tentang Penataan dan Pemberdayaan Pedagang Kaki Lima di DKI Jakarta. Di dalam penelitian ini peneliti berusaha untuk menggali, mengungkap informasi tentang permasalahan penelitian implementasi Pergub DKI Jakarta Nomor 10 Tahun 2015 tentang Penataan dan Pemberdayaan Pedagang Kaki Lima kemudian berusaha untuk menggambarkannya. Hasil penelitian berupa data-data yang diperoleh melalui wawancara dengan pejabat Pemerintah Daerah DKI Jakarta, pejabat Satpol PP DKI Jakarta, dan Dinas Perdagangan dan Pasar, serta didukung data-data dokumentasi.

Sebelum menggambarkan dan membahas mengenai implementasi Pergub DKI Jakarta Nomor 10 Tahun 2015 tentang Penataan dan Pemberdayaan Pedagang Kaki Lima, akan diuraikan dulu mengenai pertimbangan Pemerintah Daerah DKI Jakarta dalam mengeluarkan Pergub DKI Jakarta Nomor 10 Tahun 2015 tentang Penataan dan Pemberdayaan Pedagang Kaki Lima.

Pertimbangan Pemerintah Daerah Dalam Mengeluarkan Pergub DKI Jakarta Nomor 10 Tahun 2015 tentang Penataan dan Pemberdayaan Pedagang Kaki Lima
Pertimbangan tersebut didasarkan bahwa keberadaan pedagang kaki lima sebagai salah satu pelaku usaha di sektor informal yang mempunyai pengaruh cukup besar terhadap perekonomian rakyat di DKI Jakarta yang jika keberadaannya dimanfaatkan dengan baik. Akan tetapi dalam perkembangannya, jumlah pedagang kaki lima di DKI Jakarta yang semakin banyak, tumbuh dan berkembang secara alami sehingga keberadaan pedagang kaki lima di DKI Jakarta tidak tertata dengan rapi sehingga menimbulkan gangguan keamanan, ketenteraman, ketertiban masyarakat, kenyamanan, kebersihan lingkungan dan menghambat kelancaran lalulintas karena para pedagang kaki lima di DKI Jakarta telah memanfaatkan trotoar jalan, badan jalan atau fasilitas umum untuk berjualan. Berdasarkan kondisi tersebut Pemerintah DKI Jakarta melakukan upaya pengaturan terhadap kegiatan usaha yang dilakukan pedagang kaki lima agar keberadaan pedagang kaki lima tertata dengan rapi dan dapat menjaga ketenteraman dan ketertiban masyarakat dengan mengikutsertakan keterlibatan masyarakat khususnya para pedagang kaki lima.

Kebijakan Pemerintah Daerah DKI Jakarta dalam mengatur keberadaan pedagang kaki lima adalah merupakan salah satu upaya untuk mengembalikan fungsi daerah milik jalan sesuai dengan peruntukkannya. Upaya tersebut dilakukan melalui kegiatan penataan lokasi usaha bagi pedagang kaki lima, pemberian izin lokasi usaha bagi pedagang kaki lima, pemberian sanksi, dan pemberdayaan terhadap pedagang kaki lima. Pemerintah Daerah DKI Jakarta berharap dengan adanya kegiatan- kegiatan tersebut dapat tercipta kegiatan usaha pedagang kaki lima yang sehat dan meningkatkan pendapatan pedagang kaki lima seperti apa yang diamanatkan di dalam Peraturan Daerah DKI Jakarta Nomor 8 Tahun 2007 tentang Penataan dan Pemberdayaan Pedagang Kaki Lima.

Keberadaan pedagang kaki lima di DKI Jakarta yang semakin bertambah dan berkembang secara pesat dan alami sehingga perlu dilakukan penataan dan pemberdayaan terhadap pedagang kaki lima. Semakin banyaknya jumlah pedagang kaki lima di DKI 
Jakarta membuat pinggir jalan, trotoar, dan fasilitas umum dipenuhi dengan pedagang kaki lima yang melakukan kegiatan usahanya sehingga trotoar yang seharusnya diperuntukkan bagi pengguna jalan kini dimanfaatkan para pedagang kaki lima untuk berjualan. Akibat yang ditimbulkan dari banyaknya pedagang kaki lima yang memanfaatkan trotoar jalan dan fasilitas umum lainnya yaitu, merusak keindahan jalan, lingkungan menjadi kumuh, mengganggu ketenteraman dan kenyamanan masyarakat dan menyebabkan kemacetan lalulintas.

Berdasarkan hal tersebut, maka di DKI Jakarta perlu adanya penataan dan pemberdayaan pedagang kaki lima agar tercipta rasa tertib, aman dan nyaman bagi masyarakat dan pedagang kaki lima. Menurut hasil wawancara dengan Riyadi selaku Kasubag BUMD DKI Jakarta, bahwa penataan dan pemberdayaan pedagang kaki lima sangat diperlukan karena melihat semakin banyaknya pedagang kaki lima dan tempatnya sudah kumuh dan tidak sesuai dengan maksud keberadaan pedagang kaki lima. Pedagang kaki lima yang diharapkan yaitu bisa tertata, rapi, bersih, nyaman, akan tetapi keberadaan pedagang kaki lima di lapangan tidak seperti yang diharapkan karena masih saja tempat-tempat pedagang kaki lima yang tidak bersih, kurang nyaman, dan tidak tertata.

Di mana penataan dilakukan di tempattempat stratregis terutama Muntilan, dan Grabak. Para pedagang kaki lima di DKI Jakarta perlu ditata karena melihat keberadaan pedagang kaki lima sekarang tidak sesuai dengan yang diharapkan, lingkungan kumuh, kurang tertata, pengguna jalan menjadi terganggu dengan keberadaan pedagang kaki lima. Maka dari itu perlu ditata, ditertibkan dan diarahkan sesuai dengan penggunaan lahan yang digunakan berjualan oleh pedagang kaki lima. Karena badanbadan jalan yang seharusnya digunakan untuk pejalan kaki dan kendaraan tetapi digunakan untuk berjualan pedagang kaki lima.

Menurut hasil wawancara dengan Sugito selaku Sekretaris Dinas Perdagangan dan Pasar DKI Jakarta, bahwa penataan dan pemberdayaan pedagang kaki lima di DKI Jakarta sangat diperlukan untuk mengatur, melindungi pedagang kaki lima dalam mencari nafkah, banyak di daerah lain terjadi penggusuran, penertiban.

Perda DKI Jakarta Nomor 8 Tahun 2007 Tentang Ketertiban Umum dimaksudkan untuk menata pedagang kaki lima, di mana tempat yang diperbolehkan untuk berjualan sehingga dalam menjual barang dagangannya para pedagang kaki lima berjualan di tempat yang sudah disesuaikan tata ruang yang diperbolehkan di dalam Peraturan Daerah DKI Jakarta Nomor 8 Tahun 2007, dan tempatnya juga sudah mendapatkan izin dari pemilik lahan sehingga tidak menimbulkan pertentangan dan yang dapat mengganggu ketertiban dan ketenteraman masyarakat sekitar. Inti mengapa perlu ada penataan dan pemberdayaan PKL yaitu untuk memberikan perlindungan hukum bagi para pedagang kaki lima agar dalam berjualan tidak lagi mendapat gusuran dan penertiban, mendapatkan kemantapan dalam berjualan dan mendapatkan izin dalam berjualan. Selain itu para pedagang kaki lima dapat bersikap tertib dalam berjualan.

Penataan dan pemberdayaan pedagang kaki lima di DKI Jakarta seperti di daerah Kecamatan Setia Budi Jakarta Selatan yang melakukan kegiatan usaha pada sore sampai malam hari di Jalan Anggrek, Jalan Garnisun, Jalan Setiabudi Raya, belakang plaza 89 sangat diperlukan agar tercipta kondisi yang tertib, aman, nyaman, dan tidak menimbulkan kemacetan lalulintas, juga bertujuan agar lingkungan nyaman, indah, tertata, dan pengguna jalan tidak terganggu dengan keberadaan pedagang kaki lima. Selain itu, memberikan peran aktif kepada pedagang kaki lima dalam menjaga ketenteraman, ketertiban dan keamanan DKI Jakarta sehingga nantinya keberadaan pedagang kaki lima dapat diminati banyak masyarakat.

\section{Sosialisasi Pergub DKI Jakarta Nomor 10 Tahun 2015 tentang Penataan dan Pemberdayaan Pedagang Kaki Lima}

Program Pemerintah Daerah Jakarta dalam rangka mengatur keberadaan pedagang kaki lima di DKI Jakarta adalah mengeluarkan suatu kebijakan khusus bagi pedagang kaki lima yaitu Pergub DKI Jakarta Nomor 10 Tahun 2015 tentang Penataan dan Pemberdayaan Pedagang Kaki Lima. Sebagai 
tindak lanjut, Pemerintah Daerah DKI Jakarta melakukan sosialisasi Pergub DKI Jakarta Nomor 10 Tahun 2015 tentang Penataan dan Pemberdayaan Pedagang Kaki Lima kepada Dinas atau Instansi terkait diantaranya Dinas Perindustrian Koperasi dan UMKM, dan Dinas Perdagangan dan Pasar DKI Jakarta.

Menurut hasil wawancara dengan Sugito selaku Sekretaris Dinas Perdagangan dan Pasar DKI Jakarta, bahwa Dinas Perdagangan dan Pasar telah melaksanakan kegiatan sosialisasi di berbagai Kecamatan di wilayah DKI Jakarta dengan melibatkan langsung pedagang kaki lima, yaitu para pedagang kaki lima yang berada di Muntilan, Grabak, Salaman, Secang.

Akan tetapi sosialisasi yang dilakukan Dinas Perdagangan dan Pasar tidak secara menyeluruh melibatkan pedagang kaki lima, tetapi hanya diambil perwakilan dari masingmasing wilayah atau Kecamatan.

Dalam melaksanakan penataan dan pemberdayaan pedagang kaki lima di DKI Jakarta disesuaikan dengan Pergub DKI Jakarta Nomor 10 Tahun 2015 yang meliputi penentuan lokasi usaha pedagang kaki lima, pemberian izin lokasi bagi pedagang kaki lima, dan pemberian hak, dan kewajiban bagi pedagang kaki lima di DKI Jakarta. Pelaksanaan penataan pedagang kaki lima di DKI Jakarta perlu dilakukan karena melihat kondisi pedagang kaki lima yang semakin bertambah dan berkembang dan masih banyak pedagang kaki lima yang tidak memiliki izin usaha. Misalnya para pedagang kaki lima yang melakukan kegiatan usaha pada sore sampai malam hari.

Kendala-Kendala Yang Dihadapi dan Upaya Pemerintah Daerah DKI Jakarta dalam Penataan dan Pemberdayaan Pedagang Kaki Lima

Keberadaan pedagang kaki lima yang semakin banyak di DKI Jakarta dan masih kurang tertata rapi dan menimbulkan kesan semrawut menjadi permasalahan yang harus segera diselesaikan oleh Pemerintah Daerah DKI Jakarta agar keberadaannya tidak mengganggu ketenteraman dan ketertiban masyarakat, kenyamanan, keamanan, dan kemacetan lalulintas.

Oleh karena itu Pemerintah DKI Jakarta mengesahkan Pergub DKI Jakarta Nomor 10 Tahun 2015 tentang Penataan dan Pemberdayaan Pedagang Kaki Lima. Dan tentunya dalam pelaksanaan penataan dan pemberdayaan pedagang kaki lima di DKI Jakarta perlu didukung sesuai dengan prosedur pelaksanaannya agar hasilnya dapat sesuai dengan yang diharapkan.

Akan tetapi kenyataan di lapangan bahwa dalam pelaksanaan penataan dan pemberdayaan pedagang kaki lima di DKI Jakarta belum sesuai dengan apa yang diharapkan selama ini.

Dalam penataan dan pemberdayaan pedagang kaki lima di DKI Jakarta masih terdapat kendala-kendala yang dihadapi Pemerintah Daerah DKI Jakarta. Menurut hasil wawancara dengan Sugito selaku Sekretaris Dinas Perdagangan dan Pasar DKI Jakarta, bahwa pelaksanaan penataan dan pemberdayaan pedagang kaki lima di DKI Jakarta masih banyak kendala yang dihadapi, di antaranya dalam penerbitan izin dan di DKI Jakarta sendiri belum ada tempattempat khusus atau tempat-tempat resmi untuk pedagang kaki lima, dan juga dana untuk pembinaan kepada pedagang kaki lima juga menjadi kendala dalam penataan dan pemberdayaan pedagang kaki lima. Pedagang kaki lima tumbuh berkembang dengan alami sehingga dalam melakukan penataan dan pemberdayaan belum dapat dilakukan secara menyeluruh, pasar-pasar dan terminalterminal yang ada memang tidak dapat menampung seluruh pedagang kaki lima yang ada.

Berdasarkan hasil wawancara dengan Riyadi selaku Kasubag BUMD DKI Jakarta, bahwa kendala dalam penataan dan pemberdayaan pedagang kaki lima dari segi dana, karena dalam penataan dan pemberdayaan pedagang kaki lima membutuhkan dana di mana dana tersebut digunakan untuk penyediaan lahan bagi pedagang kaki lima, pembelian tenda-tenda, kemudian penyediaan rest area atau tempat khusus untuk berjualan bagi pedagang kaki lima, belum diberikan jaminan terhadap penggusuran pedagang kaki lima, dan masih banyak pedagang kaki lima yang tidak mengerti dan kurang paham dengan Pergub DKI Jakarta Nomor 10 Tahun 2015 tentang Penataan dan Pemberdayaan Pedagang Kaki Lima. 
Kendala-kendala yang dihadapi Pemerintah Daerah DKI Jakarta dalam penataan dan pemberdayaan pedagang kaki lima yaitu:

a. Banyak pedagang kaki lima di DKI Jakarta yang berjualan tidak pada tempatnya dan tidak tertata.

b. Masih banyak pedagang kaki lima yang tidak memiliki izin usaha.

c. Tidak ada lahan atau tempat khusus bagi pedagang kaki lima.

d. Masih banyak pedagang kaki lima yang tidak mengerti dan kurang paham tentang Pergub DKI Jakarta Nomor 10 Tahun 2015 tentang Penataan dan Pemberdayaan Pedagang Kaki Lima

e. Belum ada jaminan pengganti lokasi usaha bagi pedagang kaki lima dari Pemerintah Daerah DKI Jakarta.

Berdasarkan hal tersebut perlu dilakukan upaya atau tindakan yang dilakukan Pemerintah Daerah DKI Jakarta untuk menyelesaikan permasalahan atau kendalakendala dalam penataan dan pemberdayaan pedagang kaki lima. Karena jika tidak dilakukan suatu upaya atau tindakan dalam mengatasi kendala penataan dan pemberdayaan pedagang kaki lima maka pelaksanaan penataan pembedayaan pedagang kaki lima tidak dapat berjalan sesuai dengan yang diharapkan.

Menurut hasil wawancara dengan Riyadi selaku Kasubag BUMD DKI Jakarta, bahwa upaya yang dilakukan oleh Pemerintah Daerah DKI Jakarta sejauh ini yaitu penyediaan rest area bagi pedagang kaki lima yang rencana akan dibangun di daerah Mertoyudan, memberikan jaminan terhadap pedagang kaki lima yang mendapatkan penggusuran, menambah daya tampung pasar di masing- masing daerah DKI Jakarta.

Namun dalam kenyataan di lapangan hampir semua pedagang kaki lima di DKI Jakarta masih terkendala mengenai perizinan, maka dari itu di DKI Jakarta masih terus melakukan upaya untuk menata dan memberdayakan pedagang kaki lima terlebih pedagang kaki lima di DKI Jakarta masih sering mendapatkan penertiban dari petugas ketertiban (Satpol PP) karena mereka berjualan di tempat fasilitas umum seperti trotoar, badan jalan karena tempat tersebut merupakan tempat yang tidak boleh untuk berjualan yang nantinya dapat mengganggu ketertiban dan kenyamanan masyarakat.

Oleh karena itu, upaya atau usaha yang dilakukan Pemerintah Daerah DKI Jakarta dalam mengatasi kendala-kendala penataan dan pemberdayaan pedagang kaki lima yaitu:

a. Memberikan lokasi usaha bagi pedagang kaki lima dan menata pedagang kaki lima agar tertata dengan rapi

b. Memberikan izin usaha bagi pedagang kaki lima agar mendapat perlindungan hukum.

c. Penyediaan rest area bagi pedagang kaki lima

d. Memberikan penyuluhan dan pembinaan terhadap pedagang kaki lima agar paham dan mengerti mengenai Pergub DKI Jakarta Nomor 10 Tahun 2015 tentang Penataan dan Pemberdayaan Pedagang Kaki Lima.

e. Menambah daya tampung pasar di masing-masing daerah DKI Jakarta dan memberikan tempat yang sudah ditempati pedagang kaki lima tetapi harus menaati peraturan

\section{KESIMPULAN}

Dari pembahasan tersebut, peneliti menyimpulkan beberapa hal berikut ini:

1. Dalam mengimplementasikan Program Pemerintah Daerah Jakarta dalam rangka mengatur keberadaan pedagang kaki lima di DKI Jakarta adalah mengeluarkan suatu kebijakan khusus bagi pedagang kaki lima yaitu Pergub DKI Jakarta Nomor 10 Tahun 2015 tentang Penataan dan Pemberdayaan Pedagang Kaki Lima. Sebagai tindak lanjut, Pemerintah Daerah DKI Jakarta melakukan sosialisasi Pergub DKI Jakarta Nomor 10 Tahun 2015 tentang Penataan dan Pemberdayaan Pedagang Kaki Lima kepada Dinas atau Instansi terkait diantaranya Dinas Perindustrian Koperasi dan UMKM, dan Dinas Perdagangan 
dan Pasar DKI Jakarta. Dalam melaksanakan penataan dan pemberdayaan pedagang kaki lima di DKI Jakarta, harus disesuaikan dengan Pergub DKI Jakarta Nomor 10 Tahun 2015 yang meliputi penentuan lokasi usaha pedagang kaki lima, pemberian izin lokasi bagi pedagang kaki lima, dan pemberian hak, dan kewajiban bagi pedagang kaki lima di DKI Jakarta.

Pelaksanaan penataan pedagang kaki lima di DKI Jakarta perlu dilakukan karena melihat kondisi pedagang kaki lima yang semakin bertambah dan berkembang dan masih banyak pedagang kaki lima yang tidak memiliki izin usaha.

2. Kendala-kendala yang dihadapi Pemerintah Daerah DKI Jakarta dalam penataan dan pemberdayaan pedagang kaki lima yaitu:

a. Banyak pedagang kaki lima di DKI Jakarta yang berjualan tidak pada tempatnya dan tidak tertata.

b. Masih banyak pedagang kaki lima yang tidak memiliki izin usaha.

c. Tidak ada lahan atau tempat khusus bagi pedagang kaki lima.

d. Masih banyak pedagang kaki lima yang tidak mengerti dan kurang paham tentang Pergub DKI Jakarta Nomor 10 Tahun 2015 tentang Penataan dan Pemberdayaan Pedagang Kaki Lima.

e. Belum ada jaminan pengganti lokasi usaha bagi pedagang kaki lima dari Pemerintah Daerah DKI Jakarta.

3. Strategi yang harus diambil terkait dengan persoalan pedagang kaki lima serta pengemis seharusnya mengacu pada strategi yang dirumuskan pada Rencana Pembangunan Jangka Menengah Daerah (RPJMD) 2017 - 2022 di antaranya yaitu: optimalisasi pemanfaatan sumber daya kota yang mencakup aset Human,
Social, Cultural, Intelectual and Creative, Natural, Environmental dan Infrastructure, dalam rangka memberikan kontribusi guna terwujudnya kota Jakarta yang nyaman dan sejahtera untuk semua serta berkelanjutan., Konsistensi dalam implementasi Peraturan Daerah tentang Rencana Tata Ruang Wilayah, penegakan hukum terhadap pelanggaran baku mutu lingkungan, mengembalikan keadaan udara bersih, laut biru dan air tanah yang tidak tercemar, dan Membangun model kebersamaan antara pemerintah, masyarakat dan pemangku kepentingan lainnya dalam rangka menyelesaikan berbagai masalah, menjawab tantangan masa depan, dan memanfaatkan potensi dan peluang yang dimiliki kota.

\section{DAFTAR PUSTAKA}

Abdul Khadir Muhammad. Hukum dan Penelitian Hukum. PT Citra Aditya Bakti. Bandung. 2004

Adrian Sutedi, Hukum Perizinan dalam Sektor Pelayanan Publik. Sinar Grafika. 2010

Alisjahbana. Marginalisasi Sektor Informal Perkotaan. Surabaya: ITS Press. 2006 Andreas Limongan. 2001. "Masalah Pengangguran di Indonesia."

Aplikasia, Jurnal Aplikasi llmu-ilmu Agama, Vol. VI, No. 1 Juni 2005:1-13 Pendekatan Andragogi dalam Pengembangan Masyarakat hal. 9.

Bahder Johan Nasution.. Bandung Metode Penelitian Ilmu Hukum Mandar Maju. 2008 Basah, Sjachran. Pencabutan Irin Salah Satu Sanksi Hukum Administrasi. Makalah pada Penataran Hukum Administrasi dan Lingkungan Fakultas Hukum Universitas Airlangga Surabaya, 2005

Dodi Indra Sukmaya, Opini Masyarakat tentang Pedagang Kaki Lima di Lingkungan Masjid Al- Akbar Surabaya. Fakultas Ilmu Administrasi UPN Veteran Jawa Timur. 2003

Edi Suharto, Membangun Masyarakat Memberdayakan Rakyat, (Bandung: Refika Aditama, 2010) 
Edward III, George C. (edited). 1984. Public Policy Implementing. Jai Press Inc, London-England.

Grindle, Merilee S. (Ed). 1980. Politics and Apolicy Implementation in the Third World, New Jersey: Princetown University Press.

Jurnal Pendidikan dan Pemberdayaan Masyarakat Volume 2 - Nomor 2, November 2015, (226 -238) hal 2.

Malhotra, Naresh and Birks, David (2007) Marketing Research: an applied approach: 3 rd European Edition, Harlow, UK. Pearson Education

Mencegah Dan Menanggulangi Penyalahgunaan Napza Melalui Per an Serta Masyarakat, Informasi, Vol. 16 No. 01 Tahun 2011.

Meter, Donal, Van and Carl E. Van Horn. The Policy Implementation Process. Sage Publication: Beverly Hill.

N.M, Spelt, J.B.J.M. Ten Berge, Philipus.M.Hadjon, Pengantar Hukum Perizinan, Yuridika, 1993

Nakamura, Robert T and Frank Smallwood, 1980, The Politics of Policy Implementation, New York; St. Martins Press

Peter Mahmud Marzuki, Penelitian Hukum. Jakarta, Kencana. 2008

Riyadi dan Bratakusumah, Deddy. 2004. "Perencanaan Pembagunan Daerah: Strategi Menggali Potensi dalam Otonomi Daerah”. Gramedia Pustaka Utama. Jakarta.

Selayang Pandang Dinas Tramtib dan Linmas Provinsi DKI Jakarta, 2019. Bahan Sosialisasi Islamy (2002) dalam Gani, Abdul Yuli Andi, 2006. Memunculkan Tindakan Kolektif dalam Proses Pembuatan Kebijakan Publik (Suatu Studi tentang Penataan PKL di Kota Malang dengan melibatkean Stakeholders) dalam Jurnal Ilmiah Administrasi Publik Vol. VI, No. 2, Maret-Agustus 2006.

Soedikno Mertokusumo, Sebuah Pengantar Penemuan Hukum. Liberty Yogyakarta, 2007Soemardjan, Masyarakat dan Kebudayaan, (Jakarta: Djambatan, 1998)

Soetandoyo, Wignjosoebroto. Hukum dalam Masyarakat. Bayumedia Surabaya. 2008.

Sugiyono. Metode Penelitian Pendidikan Pendekatan Kuantitatif, kualitatif, dan R\&D. Bandung: Alfabeta, 2010.

Soerjono Soekanto, Pengantar Penelitian Hukum, Penerbit Universitas Indonesia (UI-Press). 2008
Surjadi, Pembangunan Masyarakat Desa, (Bandung: Mandar Maju, 1989)

Susno Danuaji dalam "Polda Seluruh Indonesia Serentak Ringkus Preman." Dalam Koran Media Indonesia, Senin, 10 November 2019

Undang-undang No. 12 Tahun 2011 tentang Pembentukan Peraturan Daerah Undang-undang No. 23 Tahun 2014 tentang Pemerintahan Daerah

Utrecht, E. Pengantar Hukum Administrasi Negara. Cetakan Kedelapan. Jakarta:Ichtiar 1957

Wibawa, Samodra.1994. Evaluasi Kebijakan Publik. Jakarta: PT Raja Grafindo Persada 